\title{
CENCHRUS LAYSANENSIS (Gramineae) of the LEENARD ISLANDS
}

\author{
Hawaiian Plant Studies 47
}

\begin{abstract}
Harold St. John
B. P. Bishop Museum, Honolulu, Hawaii, 96818, USA.
\end{abstract}

Cenchrus laysanensis (F. Br. in Christoph. \& Caum) comb. nov C. agrimonioides Trin., var. laysanensis F. Br. in Christoph. \& Caum., B. P. Bishop Mus., Bull. 81: 20, 1931; Degener \& Whitney, Fl. Haw., fam. 47: 5/14/37; Lamoureux, Atoll Res. Bull. 79:2, 1961; and 97: 2, 1963. Fig. 1 .

C. agrimonioides sensu Delisle, in part, Iowa state Journ. Sci. 37: 329, 1963, non Trin., 1826.

Original Diagnosis: "Perennial, stems branched, prostrate and creeping at the base, ascending, subscandent, 50-200 cm. in length, leaf-bearing throughout, scabrous below the inflorescence, glabrous or nearly so elsewhere. Leaf blades linear lanceolate, $30 \pm \mathrm{cm}$. long $2 \pm \mathrm{cm}$. broad, scabrous; sheaths longer than the internode, compressed, keeled, loosely clasping; ligule ciliate, $2 \mathrm{~mm}$. in length. Spikes 8-14 + $\mathrm{cm}$. long, the axis, pedicels and base of involucres densely puberulent; involucres closely arranged on pediceis $1-2 \mathrm{~mm}$. in lenyth, turbinate, $1 \pm \mathrm{cm}$. in length; outer bristles numerous, spreading, slender, $2 \pm \mathrm{mm}$. in length, retrorsely scabrous; midäle series of bristles somewhat longer and stouter than the outer, suberect, retrorsely scabrous near the apex, villose below; inner series stout, retrorsely scabrous near the apex, thickened and villose below, connate only at the base or irregularly fusca up to two-thirds the length of the bur; spikelets single in each involucre; glumes all broadly triangular and acute or cuspidate, the basal ones 2-4 mm. long, 1-5-veined; second glume 5-7 + mm. in length, 5-9-veineä; third glume 6-7 + mm in length, 7-12-veined, with a thin 2-7-veined staminate palea in the axil; fourth glume 6-7 $+\mathrm{mm}$ in length, 7-11-veined, enclosing a 3-7-veined bisporangiate palea."

This grass has had varying classifications. It was first mentioned by Hitchcock (1922: 211) who said, "The Laysan specimens have somewhat larger burs and flat blades $15-20 \mathrm{~cm}$ long and 1 to $2 \mathrm{~cm}$. wide, and the base of the bur is more abruptly enlarged upward. 
These may represent a distinct species. The specimens are said to be 3 or 4 feet tall."

Then, in 1931, F. B. H. Brown gave a detailed description of it and named it C. agrimonioides, var.

laysanensis.

In 1937 O. Degener and L. D. Whitney accepted this var. laysanensis and confirmed its characters, except

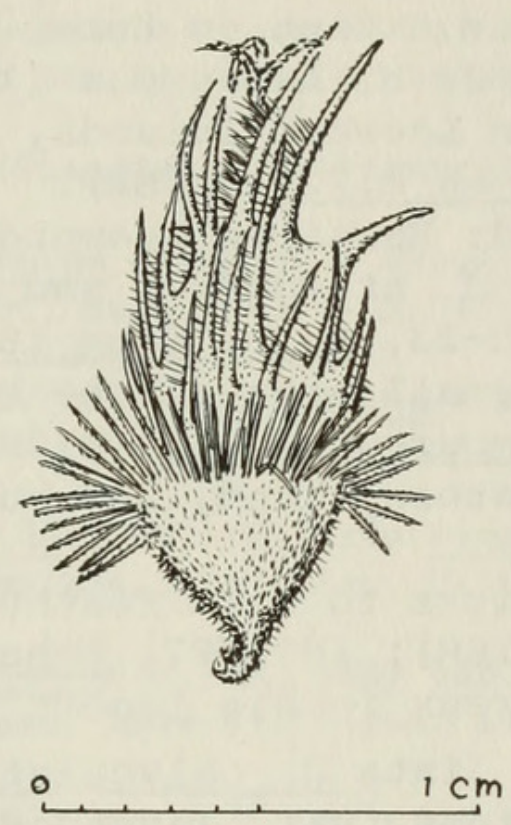

Fig. 1. Cenchrus laysanensis, bur of holotype, X 4 .

for the one claimed by Brown in the number of nerves on glumes and palea.

In 1963 D. G. Delisle published a monograph of the genus. He accepted (p. 329) C. agrimonioides Trin. as an endemic species of the Hawaiian Islands, but to its synonymy he reduced the var. laysanensis and

C. pedunculatus Deg. \& Whitney. As a result of this lumping, Delisle in his description gave a wide range of limits, as culms $35-200 \mathrm{~cm}$ tall; blades 6-16 mm wide; racemens $7.8-28 \mathrm{~cm}$ long; burs 10-14.2 mm long; inner spines connate at the base or often for some distance above the base.

The writer accepts c. pedunculatus Deg. \& Whitney, and its characters were well presented by its authors.

C. agrimonioides Trin. is characterized by being a perennial 40-67 cm tall; blades 4-12 mm wide; burs 8-12 mm long; inner spines free to the base or nearly so. 
It occurs on the lower mountain slopes of Oahu, east Maui, and Lanai.

C. laysanensis is a coarse, thick-stemmed perennial 1-2 m tall; blades 10-24 mm wide; burs 11-15 mm long; inner spines unitea $\frac{1}{2}-2 / 3$ their length. It occurs only on the low, ary atolls of the northwestern Hawaiian Leeward Islands. The holotype was from Laysan Island. The species was last collected on Midway Island in 1902; and on Laysan in 1911. It is certainly extinct on these two islands, but it is extant on Kure, where it was collecteà in 1961 by C. H. Lamoureux (1961: 2).

Holotype: Hawaiian Leeward Islands, Laysan Island, April 1911, W. A. Bryan 8,729 (BISH).

Specimens Examined: Hawaiian Leeward Islands:

Kure (ocean) Island, at edge of and near central plain, 4 m alt., 4-18-23, E. L. Caum 18 (BISH); half a dozen clumps in one small area of the central plain, IX-12-1961, C. H. Lamoureux 1,912 (BISH, HAW).

Midway Island, Easternisland, 2-3 bunches, 8-23-02, W. A. Bryan (BISH).

Laysan Island: sticks to bird feathers, April 1903, W. A. Bryan 8,728 (BISH); 1896/97, Schauinsland (BISH).

Discussion: Lamoureux in his report on the flora of Kurels land (1963: 2) lists C. calyculatus Cav. as a synonym of $\underline{c}$. agrimonioides, var. laysanensis. $\underline{c}$. caliculatus Cav. is, however, maintained as a species by Delisle in his monograph, known from Australia and South Pacific Islands, as far east as Mangareva, but not for Hawaii.

The only other species of Cenchrus known to occur in the Leeward Islands is the abundant and widespread weed, C. echinatus L., which is evidently native to the Americas.

\section{Bibliography}

DeLisle, Donald G. Taxonomy and distribution of the genus Cenchrus. Iowa state Journ. Sci. $37(3)$ : 259-351, figs. $1-22$.

Hitchcock, A. S. 1922. The Grasses of Hawaii. B. P. Bishop Mus., Mem. 8(3): 101-230, pl. XXXI-XXXV, figs. 1-110. Lamoureux, Charles H. 1961. Botanical observations on Leeward Hawaiian Atolls. Atoll Res. Bull. 79: 1-10, 1 photo.

1963. The flora and vegetation of Laysan Island. Atoll Res. Bull. 97: 1-14, figs. 1-12. 


\section{$2 \mathrm{BHL}$ Biodiversity Heritage Library}

St. John, Harold. 1975. "Cenchrus laysanensis (Gramineae) of the Leeward Islands." Phytologia 31, 22-24. https://doi.org/10.5962/bhl.part.12118.

View This Item Online: $\underline{\text { https://www.biodiversitylibrary.org/item/47028 }}$

DOI: https://doi.org/10.5962/bhl.part.12118

Permalink: https://www.biodiversitylibrary.org/partpdf/12118

\section{Holding Institution}

New York Botanical Garden, LuEsther T. Mertz Library

\section{Sponsored by}

The LuEsther T Mertz Library, the New York Botanical Garden

\section{Copyright \& Reuse}

Copyright Status: In copyright. Digitized with the permission of the rights holder.

Rights Holder: Phytologia

License: http://creativecommons.org/licenses/by-nc-sa/3.0/

Rights: https://biodiversitylibrary.org/permissions

This document was created from content at the Biodiversity Heritage Library, the world's largest open access digital library for biodiversity literature and archives. Visit BHL at https://www.biodiversitylibrary.org. 